\title{
Placing Presidential-Congressional Relations in Context: A Comparison of Barack Obama and his Predecessors
}

\author{
Jeffrey E. Cohen \\ Professor \\ Department of Political Science \\ Fordham University \\ Bronx, NY 10458 \\ (718) 817-3956 (office) \\ (718) 817-3972 (fax) \\ cohen@fordham.edu \\ Jon R. Bond \\ Professor \\ Department of Political Science \\ 4348 TAMU \\ Texas A\&M University \\ College Station, TX 77843-4348 \\ (979) 845-4246 (office) \\ (979) 847-8924 (fax) \\ jonbond@polisci.tamu.edu \\ Richard Fleisher \\ Professor \\ Department of Political Science \\ Fordham University \\ Bronx, NY 10458 \\ (718) 817-3952 (office) \\ (718) 817-3972 (fax) \\ fleisher@fordham.edu
}

Paper presented at the U.S 2012 Presidential Election: Campaign and Results Conference,

Interdisciplinary Center, Herzliya, Israel, January 6-7, 2013 


\begin{abstract}
What better accounts for Barack Obama's success with Congress, his political skills or aspects of the political context, such as party control of Congress and public approval? To address this question, we update the Bond-Fleisher-Wood (BFW) political context model through 2010. The BFW model accounts for Obama's success vis-à-vis the House, to some extent, for the Senate as well. This article argues that increasing party polarization affects the relationship between party control and presidential success differently in the House and Senate. In the supermajoritiarian Senate, greater partisanship diminishes the effects of party control—in other words, as party polarization increases, presidential success declines for both majority and minority presidents. A comparison of Obama's success with that of previous presidents facing a similar context reveals no evidence that Obama has won significantly more often than should be expected given the context.
\end{abstract}

Keywords: president, presidential success in Congress, Barack Obama 


\section{Placing Presidential-Congressional Relations in Context: A Comparison of Barack Obama and his Predecessors}

In his first two years in office, Barack Obama could boast of enactment of several landmark pieces of legislation, including economic stimulus, financial industry reform, health care reform, major tax legislation, and repeal of the "Don't Ask-Don't Tell" policy with regard to gays serving in the military. His success in sponsoring legislation also seems quite impressive. During his first years in office, his legislative proposals won 93 and 86 percent of House votes and 98 and 75 percent of Senate votes. The average success rates for other presidents, who like him, benefited from majority control were 77.5 in the House and 73.9 in the Senate. Given the gridlock, partisan bickering, and party polarization that characterize current American politics, these legislative success rates surely represent major achievements.

Some scholars attribute Obama's successes to his political skills. For instance, Fred Greenstein observes that Obama is "a gifted public communicator", that his "prepresidential record shows ample evidence of his political skill", that he is intelligent and open-minded, and that "the Barrack Obama of today may be the rare political leader who has a first-rate temperament and a first-rate mind." ${ }^{1}$ Stanely Renshon describes Obama as having "supple intelligence, policy knowledge, and substantial rhetorical skills.", According to journalist Peter Slevin, Obama honed his political skills in the rough and tumble of Illinois politics, which prepared him for political life in Washington. ${ }^{3}$

The idea that a president's skills affect his success with Congress has a long and venerable tradition in presidential studies. Richard Neustadt argued that skilled presidents use their skill or reputation for skill to overcome disadvantages in various bargaining situations. "[A]ny President who valued personal power would start his term with vivid demonstrations of his tenacity and skill

in every sphere ... ${ }^{4}$ Due to their individual skill sets, a president may be "uncommonly 
successful" according to Roger Davidson. ${ }^{5}$ Several comparative studies argue that skills account for success. ${ }^{6}$ Numerous presidential biographies and case studies of legislative episodes also stress the importance of personal skills in leadership success. $^{7}$

Another tradition, however, argues that the political context determines presidential success: Presidents can expect a high degree of success when the context is favorable, such as when the president's party controls Congress and when public approval is high. Success will decline when the context is not so favorable. ${ }^{8}$ In their study of ten presidents who served from 1953-2001, Fleisher, Bond, and Wood detected no evidence that political skills helped explain congressional success beyond context. They found that some presidents' success varied unpredictably from Congress to Congress, and during the same Congress, some presidents were more successful in one chamber than in the other. Even presidents commonly cited for their political skills, like LBJ or Reagan, did not enjoy greater success once context is considered in their analysis; and others like Nixon and Carter, who allegedly lacked political skill, were not less successful than their peers once context is taken into account. ${ }^{9}$

Thus we have two types of explanations for presidential success with Congress - political skill and political context. Which type better explains Obama's success with Congress? To address this question, we update the Bond, Fleisher, Wood (BFW) political-context model through 2010. The model accounts for Obama's success in the House quite well; it does less well predicting success in the Senate. The declining predictive power of the BFW model for the Senate, however, does not appear to be due to Obama's political skills. We shall argue that party polarization combined with the increasing use of supermajoritarian in the Senate decision rules better accounts for weaker statistical fit of the model.

\section{Political Context and Presidential Success in Congress}


Past research has identified several variables that influence members' of Congress roll-call behavior. The BFW model focuses on party control, presidential honeymoons, presidential approval, and party polarization.

\section{Party Control and Presidential Success}

According to George Edwards and Jon Bond and Richard Fleisher, the foremost factor affecting presidential success with Congress is party control. ${ }^{10}$ Presidential support is higher among members of the president's party than among the opposition. As a result, the president's position is more likely to win more votes when his party controls Congress than when the opposition party is in power.

Past research has identified multiple reasons for the strong influence of party on congressional behavior. First, because members of the same political party must satisfy similar electoral coalitions, they share a wide range of policy preferences. Co-partisans and their constituents are therefore more likely to agree with the president's policy preferences than are opposition party members. Second, members of the president's party must run on his record as well as their own, which provides them with an incentive to help him succeed. In addition, the majority party controls important levers of power in Congress, including committees, access to the floor, and rules governing debate and roll call voting. So, the issues on the congressional agenda and presentation of choices to members are more likely to reflect the president's preferences when his party controls the chamber. ${ }^{11}$

\section{The Presidential Honeymoon}

New presidents also tend to enjoy higher success early in their first terms. During the so-called honeymoon, the public, the Washington press corps, and members of Congress are predisposed to give a newcomer the benefit of the doubt. As a result, this period is widely viewed as the most propitious time for presidential initiatives. ${ }^{12}$ Paradoxically, the first year is also a period of learning and adjustment for the president, so there is no guarantee that he will be able to exploit the potential benefits of the honeymoon. ${ }^{13}$ 


\section{Popular Support}

Public approval provides a third source of presidential success in Congress. According to Neustadt, the president's popularity affects calculations of electoral self-interest among members of Congress because they fear electoral retribution if they either oppose a popular president or support an unpopular one. In Neustadt's words: members of Congress “must take account of popular reactions to their actions. What their publics think of them becomes a factor, therefore, in deciding how to deal with the desires of a President. His prestige enters into that decision; their publics are part of his."14

Public approval, however, should have only a marginal effect on presidential success because of other, often more powerful, forces influencing members' roll-call votes, such as constituency and party. ${ }^{15}$ For instance, members of Congress may vote against a popular president who takes a position on an issue that their constituents oppose. ${ }^{16}$

\section{Party Polarization}

Party polarization in Congress is the final major political context factor that affects presidential success. Polarization, however, has an indirect effect on success. According to Bond, Fleisher and Wood, during periods of low party polarization an increasing number of members of Congress experience conflicts among their cues, such as party and ideology, when they decide how to cast their votes. When many members experience such conflict, the level of public approval for the president becomes more influential in their decisions. During periods of high partisanship, there are fewer cross-pressured members, and the effect of public approval declines. ${ }^{17}$

Party polarization also conditions the relationship between party control and presidential

success. Presidents typically champion the preferences of their party's mainstream. ${ }^{18}$ When parties are polarized, presidential cues reinforce the primary cues of members from his party, which results in fewer defections and which leads to higher success if his party controls the chamber. 
The effects, however, are likely to differ in the House and Senate. Two features of the Senate tend to insulate Senators from popular influences and to mute the effects of both public opinion and party. First, Senators serve six-year terms, and only one-third face the voters in any given election. The president's popularity is not likely to affect the reelection chances of the two-thirds of Senators whose next election is more than two years away. Second, Senate rules, such as the filibuster, allow individuals and the minority party to block legislation they oppose, whereas House rules allow even a slim partisan majority to win if it is cohesive. If parties are cohesive, the president will get greater support from his co-partisans, but less support from the opposition. Polarized parties in the House, therefore, should increase the success of majority presidents and decrease the success of minority presidents. Majority control is less of an advantage in the Senate governed by supermajoritarian decision rules, and polarized parties may reduce the advantage of majority control even more because a cohesive minority party is better able to block cloture.

\section{Variables}

We will measure the dependent variable, presidential success on the floor of the House and Senate, in terms of the annual percentage of conflictual roll calls from 1953 through 2010, the last year for which we have complete data ${ }^{19}$ We will define a conflictual presidential roll call as one on which 20 percent or more of members vote against the president. ${ }^{20}$ We will exclude consensual presidential victoriesby which we mean — to limit the analysis to relatively important issues. A casual check of issues passed by near unanimous margins with the president's support reveals that, with rare exceptions, these are minor and routine issues. Votes that the president lost with more than 80 percent voting against him will remain in the analysis. These unusual cases reflect acute inter-institutional conflict. Such cases are neither trivial nor routine, and belong in the analysis.

The most important independent variable is party control of the House and Senate, which will be measured by a dummy variable ${ }^{21}$, coded 1 when the president's party controls the chamber and 0 
otherwise. $^{22}$ We expect that other independent variables will have marginal effects on success. We will measure the honeymoon with a dummy variable, coded 1 for the first year after the president's first election and 0 otherwise. We will code Lyndon Johnson with an early honeymoon in 1964, but Gerald Ford without a honeymoon. Second term presidents will not receive a second honeymoon. ${ }^{23}$ We will use the average annual percentage approving of the president's job performance according to the Gallup job approval question_-'Do you approve or disapprove of the way [the incumbent] is doing his job as president?”

The percentage of party votes in each chamber per year will indicate party polarization in Congress. $^{24}$ The annual percentage of all recorded votes in which a majority of Democrats opposed a majority of Republicans will define party vote. We modify the usual practice and exclude consensual roll calls (that is, roll calls with 10 percent or fewer members voting in the minority). This revised measure will indicate the percentage of all conflict on roll call votes that is party conflict. ${ }^{25}$ According to the BFW model, party polarization should not affect presidential success directly, but will condition the effects of public approval and party control on success. To measure this conditional effect, we will create interaction terms by multiplying approval or party control by the percentage of party votes in each chamber. ${ }^{26}$ We will analyze the House and Senate separately, and will expect the effects of approval, party control, and the interactions to be weaker in the Senate than in the House.

\section{Results of the Updated Models}

Our analysis brings the BFW model up to date in two stages. We first extend the model from 1953 through 2008, prior to Obama's taking office. We then extend it through 2010, the last year for which we have complete data. Table 1 presents results of multivariate OLS estimations. ${ }^{27}$

The BFW model continues to fit voting patterns within the House. The model's predictions diverge somewhat from voting behavior in the Senate. The updated House models produce $\mathrm{R}^{2} \mathrm{~s}$ of .83 
and .84, up from about .77 in Fleisher, Bond, and Wood, while the updated Senate models produced $\mathrm{R}^{2} \mathrm{~S}$ of .57 and .56 compared to. 70 in the earlier analysis. ${ }^{28}$

[Table 1 about here]

Turning to the impact of specific variables, the House estimates indicate that party control, interacting with party polarization, accounts for almost all of the explained variance in presidential success as it did in the original BFW model. Contrary to the original analysis, however, public approval and the honeymoon have no significant effect in the House. Approval and the honeymoon are correlated, which may obscure their separate effects on success. Presidents typically have higher approval in their first year in office. In these data, approval and the honeymoon are correlated at $\mathrm{r}=0.35, \mathrm{p}<.01$ ), with presidential approval averaging 63.7 in honeymoon years and 53.3 for non-honeymoon years. Approval fails to attain statistical significance even if we drop the honeymoon from the equation. But, the honeymoon becomes significant when we drop approval and the interaction between approval and party voting for the 1953-2010 estimation. Under these conditions, the honeymoon almost reaches conventional statistical significance for the years 19532008.

Turning to the Senate, we see honeymoon effects but no significant effect for approval. Party control has significant effect for 1953-2008, but not in the model based on the full time series. Contrary to the BFW analysis of data through 2001, none of the interactions approaches conventional significance levels. The inclusion of so many correlated variables raises the specter of multicollinearity, which perhaps obscures the influence of party control and other variables.

Table 2 presents reduced-form equations, which include only statistically significant independent variables. ${ }^{29}$ The political-context model continues to predict presidential success quite well for the House with $\mathrm{R}^{2} \mathrm{~s}$ above .80 . Public approval no longer seems to play a significant role, perhaps because party control has become more important as party polarization in the House has 
widened. At the average level of party votes (67.7 percent), majority presidents win almost 34 percent more votes than minority presidents. The coefficient for party polarization is about -1.00 , indicating that minority presidents win about one percent fewer House votes for every one percent increase in party votes. The coefficient for the interaction term is positive 1.63 and 1.71 , indicating that majority presidents win about one-and-two-thirds percent more votes for every one percent increase in party votes.

[Table 2 about here]

The reduced Senate model indicates that presidents tend to win more often during their honeymoon year and if public approval increases. The model suggests that presidents win about eight to ten percent more often during their first year in office. The effect of public approval is more marginal - a relatively large 10-percent increase in approval ${ }^{30}$ is associated with about 2.5 percent more wins. Party control has a strong positive effect, with majority presidents winning about 20 percent more votes. As expected, the benefits of majority control are less in the Senate than in the House $(\approx 34$ percent $)$. The coefficient for party polarization is -.22 and significant, but the interaction is not significant. This result indicates that both majority and minority presidents win about 2.2 percent fewer votes with a 10 percent increase in party votes.

Figures 1 and 2 illustrate these relationships with scatter plots of presidential success against the percentage of party votes. Although the relationship overall is nil in both chambers (House $\mathrm{R}^{2}=$ .01 ; Senate $\mathrm{R}^{2}=.03$; slopes close to zero and not significant), the effect of party voting on success differs markedly for majority and minority presidents. In the House, the relationship is positive for majority presidents and negative for minority presidents - if the percentage of party votes increases 10 percent, majority party presidents win about 6.5 percent more votes while minority presidents win about 10 percent less $\left(\mathrm{p}<.001, \mathrm{R}^{2} \mathrm{~s} \approx .50\right)$. But notice that the success rates of majority and minority presidents differ only slightly when party voting falls below about 60 percent. In other 
words, if parties are not cohesive, majority presidents tend to get less support from their party and minority presidents are better able to attract support from the opposition.

[Figures 1 and 2 about here]

The relationships in the Senate are much weaker: $\mathrm{R}^{2}=.04$ for majority presidents and .07 for minority presidents (see Figure 2). The slopes are negative and of similar magnitude for both majority and minority presidents. Although the coefficients are not significant at conventional levels ( $p>.11$ and .15 for majority and minority presidents respectively), they suggest that a 10percent increase in party votes decreases the success rate about 1.9 percent for majority presidents and about 2.9 percent for minority presidents.

Changes in the political environment inside and outside of Congress help explain the changes in the performance of the model in the Senate. The 2000s was a decade of growing party polarization. The addition of these new cases alters the structure of the data as we now have more cases of high party polarization. Bond, Fleisher, and Wood have shown that factors influencing presidential success change as the political environment - especially party polarizationfluctuates. ${ }^{31}$ During periods of high polarization, party becomes a stronger voting cue for members of Congress. However, greater partisanship has different effects in the House and Senate. In the House, as the parties become more cohesive and polarized, party control balloons in importancemajority party presidents win more often and minority presidents lose more often. The Senate is a more complex story. Although party remains a significant influence on roll call voting in that chamber, Senate rules allow a minority to stall and even block issues from coming to the floor. This reduces the effect of party control on presidential success. Compared to their experiences in the House, majority-party presidents in the Senate receive a smaller boost of support, and minority party presidents lose less often. The right of unlimited debate (filibuster) and Senate rule XXII, requiring a supermajority to invoke cloture, are keys to minority power. Individual senators on both 
the right and the left have long used the filibuster to block passage of legislation they strongly opposed. Historically, filibustering was not related to party control of the chamber. ${ }^{32}$ Indeed, the majority party undertook many of the best-known filibusters. Increasing party polarization in Congress transformed the filibuster into a partisan tool. The minority party now routinely uses it to influence policymaking and to block the confirmation of presidential nominees. ${ }^{33}$ Consequently, unlike the House, high levels of party polarization in the Senate tend to lower the success rate of both majority and minority presidents.

Thus, differences in the way that party polarization conditions the relationship between party control and presidential success in the House and Senate explain the changes in the predictive power of the BFW model. The increasing party polarization after 2001 reinforced the strong relationship in the House and diminished the weaker relationship in the Senate. But can the political-context model account for Obama's success with Congress? We will use the results in Table 2 to see how well the revised and updated BFW model does in predicting Obama's success with Congress.

\section{Predicting Obama's Success with Congress}

Figures 3 and 4 present plots of the actual and predicted success rates for the House and Senate. For most years, the plots for both the House and the Senate are quite similar with only small gaps between the actual and predicted scores. Nevertheless, for several years substantial gaps appear between actual and predicted success. Moreover, they appear at different times for each chamber. In the House (Figure 3), the large gaps appear mainly during the 1960s and 1970s, with only two in recent years (2004 and 2008). In the Senate (Figure 4), the gaps occur primarily in recent years.

[Figures 3 and 4 about here]

To evaluate Greenstein's argument that Obama's skills enabled him to be uncommonly successful we will analyze the gaps between predictions and performance in two ways. ${ }^{34}$ First, we 
use the parameter estimates from the 1953-2008 estimations to forecast Obama's success with Congress in 2009 and 2010. Second, we will generate estimates for the entire time series and examine the predicted values for 2009 and 2010. The closer the statistical predictions come to Obama's actual success, the greater our confidence that political conditions account for his success, rather than his political skills.

As Table 3 shows, the political-context model, using the full data series, predicts Obama's success with nearly pinpoint accuracy in the House. It misses his rate of success by only 1.2 and 2.0 points respectively for 2009 and 2010 . The House model for 1953-2008 also performs well, albeit not as accurately as for the 1953-2010 series, which is to be expected given that the longer series has more information. This model underpredicts Obama's success in House by 4.7 points in 2009 and overpredicts his success by 6.3 points in 2010 .

The predictions, however, are not nearly as accurate for the Senate. Irrespective of estimation technique, the predictions for 2009 are wide of the mark by more than 20 percent. The 2010 estimates are somewhat better, but still miss by 11-16 percent.

\section{[Table 3 about here]}

If Greenstein's assessment is correct, we should find that Obama's success rates were significantly higher than would be expected by random chance. We will test statistical significance with a type of standardized residuals used in earlier analysis. ${ }^{35}$ Using a 95 percent confidence interval, absolute values greater than about 2.02 are considered unusual. We would expect one in twenty to appear unusual by random chance - about 2.9 unusual observations in each chamber for a sample of size 58 .

Figure 5 plots these residuals for the House and Senate. For the House we have only three studentized residuals greater than $\pm 2.0(1960,1971,1976)$; for the Senate we also have three such 
residuals $(1999,2002,2004)$, and 2009 (1.94) is close enough to count as a fourth. We would expect approximately this number of "unusual" residuals by chance. ${ }^{36}$

[Figure 5 about here]

We could not find any systematic pattern in these residuals consistent with expectations about which presidents were especially skilled or unskilled. We do not observe significant residuals in both chambers in the same year, nor do they cluster for any particular president. Although we do find two significant residuals for George W. Bush in the Senate, these unusual residuals point in opposite directions, with Bush winning significantly more than predicted in 2002 and significantly less in 2004. For presidents included in the Fleisher, Bond, and Wood study, we find a similar pattern. ${ }^{37}$ Two of the significant positive House residuals are for Eisenhower in 1960 (who is not often reputed to be unusually skilled ${ }^{38}$ ) and Nixon in 1971 (who is consistently rated as unskilled in dealing with Congress). And neither of the presidents who are reputed as highly skilled—Johnson and Reagan— show up as unusually successful in any year. Indeed, both had years in which they underperformed, and years when each did better in one chamber but worse in the other.

Looking at Obama's success, we do not observe support for the claim that he was unusually successful. His success in the House was very close to what should be expected given the context. He did win more than expected in the Senate in both years, and the residual in 2009 is near the cutoff to consider a residual unusual. In our view, this pattern does not imply that Obama was unusually successful with the Senate. First, why would Obama be more successful than expected in the Senate than in the House? We know of no theory suggesting that presidential skills would be more effective for one chamber than the other. Second, from Paul Light's "cycle of increasing effectiveness" perspective, the pattern of under-prediction in the Senate from 2009 to 2010 is puzzling. ${ }^{39}$ Light suggests that presidents become more effective over time because they learn while on the job. Hence, if presidential skills influence relations with Congress, the impact should be more obvious the longer the 
president is in office. Here we see just the opposite: the gap between Obama's actual and predicted success was much larger in 2009 than 2010.

Another approach to assessing whether Obama is uncommonly successful is to look at the performance of other presidents who dealt with polarized parties in Congress, such as Bill Clinton and George W. Bush. Party voting during the Clinton and Bush years averaged 76 and 78 percent in the House and Senate respectively. This is somewhat lower than the 88 and 90 percent during Obama's first two years in office. Still, party voting for Clinton and Bush was higher than the averages of 63 and 56 percent for previous presidents. When we focus on Clinton and Bush's first two years, (See Figure 5), we find that in both cases, the House model predicts nearly as well as it did for Obama, with success slightly less than expected in one year and slightly more in the other. The predictions for the Senate also resemble those for Obama. Clinton and Bush did better than expected in both years, but with the second year higher (significantly better for Bush), which is consistent with "cycle of increasing effectiveness" concept. Based on this evidence, it is hard to argue persuasively that Obama's political skills—extraordinary as they may be — generated a greater amount of success given the political context.

\section{Obama, the $112^{\text {th }}$ Congress and Beyond}

What does the model suggest about Obama's success in subsequent years? We know the value of the most important variable for 2011-12 — party control—and we can make educated guesses about the other variables - party polarization and public approval. The 2010 elections gave Republicans solid control of the House, but Democrats held on to the Senate. The success of extremely conservative Tea Party candidates makes it unlikely that party voting will decline in the $112^{\text {th }}$ Congress. Party voting at 90 percent is approaching the ceiling in both chambers. So, let's assume party votes will remain at 90 percent in both chambers in 2011 and 2012. Public approval is significant in the Senate model. We can assume a job approval rating in the mid-40s, the average 
for most of 2011. Predictions based on these assumptions will provide another test of the BFW political context model of presidential success, though we must wait until all the data have been generated to determine how well the model holds up.

The switch from majority to minority control with high party polarization has stunning implications for Obama's success in the House. The model predicts that his success on House roll calls should drop from 85.7 percent in 2010 to 17.4 percent in 2011 and 2012. Said differently, instead of winning on approximately $5 / 6^{\text {th }}$ of roll calls with Democrats in control of the House, Obama can expect to lose on approximately $5 / 6^{\text {th }}$ of roll calls with Republicans in the majority. Such a reversal of fortune is comparable to George W. Bush's record. He averaged 78.2 percent success during his first six years in office, when his party controlled the House, and only 22.5 percent when party control switched to the Democrats in 2007-8. Although this drop of nearly 56 points is less than the predicted 68 percent decline for Obama, we would expect a greater drop off for Obama, not because he is less skilled than Bush, but because party polarization is higher.

Predictions for the Senate remain essentially the same for 2011 and 2012 as for 2010, at around 63 percent. This assumes that his job-approval rating hovers in the mid-40s. But even a 10percent increase in approval to 55 percent would have only a modest impact on his success, about 2 percent higher than if his approval is 45 percent. We are less confident in these point estimates for the Senate than for the House, due to the weaker statistical power of the Senate estimations. Furthermore, the model assumes that the size of the majority does not significantly add to the benefit of majority control. But going from nearly 60 votes in 2009-10 to 53 (counting the two Independents) may have some affect.

\section{Conclusions}

This paper has assessed two explanations of Barack Obama's congressional success. One focuses on his personal skills and the other on the political context. We find that the political-context 
model does a good job of capturing the forces that affect presidential success. Indeed, the predictive power of the political-context model for the House has actually improved from an earlier analysis (Fleisher, Bond, and Wood 2008). ${ }^{40}$ This enhanced predictive power is due the effects of increasing party polarization from 2001 to 2010 . Because House rules enable a cohesive majority to prevail, increasing party polarization magnifies the effects of party control—majority presidents win more, minority presidents win less. An application of an updated version of the model to forecast Obama's success rate in the $111^{\text {th }}$ House of Representatives indicates that Obama's relationship with the House was very much in line with what we would expect given the performance of his predecessors under similar conditions. Additional data from Obama's first two years in office do little to change our understanding of presidential success in the House, and do not provide evidence to conclude that Obama's individual talents affected the pattern of success.

Turning to the Senate, we find that the model's predictive power is less strong but good in general. The decline in predictive power, however, does not lead us to conclude that presidential skills account for the weaker results. Although the model predicts success in the Senate less accurately than in the House, we do not find more large errors than would be expected by random chance. Moreover, the pattern of errors is not consistent with the skills hypothesis. Rather, we present evidence suggesting that party polarization is at least partially responsible. Whereas greater partisanship amplifies the effect of party control in the majoritarian House, it diminishes the effect of party control in the supermajoritarian Senate. In the Senate, as party polarization increases, success rates decline for both majority and minority presidents. Although the filibuster once was a tool that small minorities of individual Senators used to protect their interests, party polarization has transformed it into a partisan tool that the minority party uses to block policies and nominees contrary to party interest. As these supermajoritarian procedures became partisan tools, the 
frequency of their use has increased dramatically. As a result, the president's allies in the Senate increasingly need to muster 60 votes to pass major policies and get nominees confirmed.

Looking ahead to the $112^{\text {th }}$ Congress, our results suggest that Obama's success in the House will fall precipitously under Republican control. Since party polarization is higher under Obama than Bush and Clinton, the model predicts that his success rate will drop even more than was the case for earlier minority presidents. In the Senate with Democrats nominally controlling the chamber, Obama should be more successful than in the House. Nevertheless, with the increase in party polarization, we suspect that Obama may have lower levels of success than would be expected for a majority-party president dealing with less polarized parties.

With respect to the debate between skills and context as foundations for presidential success in Congress, our analysis detected no evidence that skills matter systematically, and our findings lend additional support for the context explanation. In our opinion, political context—party control in Congress, the degree of party polarization, and to a lesser extent honeymoon and public approval — determines the broad parameters of presidential success on floor votes in Congress.

Yet, the political-context model leaves much variance unexplained, and we should not necessarily dismiss political skills as irrelevant. "Skill" is an elusive concept, and no statement in the literature provides a sufficiently precise definition that would allow us to measure presidents' skillfulness and test whether it matters for success in Congress. Absence of evidence is not evidence of absence. As we move forward, scholarly energies should be devoted to the theoretical development of skill as a concept relevant to the legislative arena, with an eye on measurement and hypothesis testing. Admittedly, this task will be a difficult, but it is a necessary if we are to make progress toward a scientific understanding of presidential success in Congress. Until then, we stick by the conclusion that extraordinary political skills are rarely extraordinary enough to overcome the limits set by context. 


\begin{tabular}{|c|c|c|c|c|}
\hline \multicolumn{5}{|c|}{$\begin{array}{l}\text { Table 1: The Determinants of Presidential Success in the House and Senate, 1953-2008 and } \\
1953-2010^{*}\end{array}$} \\
\hline \multirow{2}{*}{ Variables } & \multicolumn{2}{|c|}{ House } & \multicolumn{2}{|c|}{ Senate } \\
\hline & 1953-2008 & $1953-2010$ & $1953-2008$ & 1953-2010 \\
\hline Party Control & $\begin{array}{r}-76.18 \\
(-3.96)\end{array}$ & $\begin{array}{r}-76.85 \\
(-4.63)\end{array}$ & $\begin{array}{r}\mathbf{2 6 . 1 4} \\
(1.65)\end{array}$ & $\begin{array}{l}15.33 \\
(0.96)\end{array}$ \\
\hline Honeymoon & $\begin{array}{r}3.82 \\
(1.03)\end{array}$ & $\begin{array}{r}4.35 \\
(1.23)\end{array}$ & $\begin{array}{c}\mathbf{7 . 8 7} \\
(1.70)\end{array}$ & $\begin{array}{r}9.93 \\
(2.17)\end{array}$ \\
\hline Public Approval & $\begin{array}{r}1.09 \\
(1.63) \\
\end{array}$ & $\begin{array}{r}1.03 \\
(1.58) \\
\end{array}$ & $\begin{array}{r}0.91 \\
(1.32) \\
\end{array}$ & $\begin{array}{r}0.91 \\
(1.31) \\
\end{array}$ \\
\hline Party Polarization & $\begin{array}{r}-0.33 \\
(-0.68)\end{array}$ & $\begin{array}{r}-0.37 \\
(-0.79)\end{array}$ & $\begin{array}{r}0.33 \\
(0.52)\end{array}$ & $\begin{array}{r}0.34 \\
(0.58)\end{array}$ \\
\hline Approval x Party Polarization & $\begin{array}{r}-0.01 \\
(-1.47)\end{array}$ & $\begin{array}{r}-0.01 \\
(-1.42)\end{array}$ & $\begin{array}{r}-0.01 \\
(-1.00)\end{array}$ & $\begin{array}{r}-0.01 \\
(-1.00)\end{array}$ \\
\hline Party Control x Party Polarization & $\begin{array}{r}\mathbf{1 . 6 3} \\
(5.77)\end{array}$ & $\begin{array}{r}\mathbf{1 . 6 4} \\
(6.82)\end{array}$ & $\begin{array}{r}-0.11 \\
(-0.42)\end{array}$ & $\begin{array}{r}0.08 \\
(0.33)\end{array}$ \\
\hline Constant & $\begin{array}{l}56.67 \\
(1.29)\end{array}$ & $\begin{array}{r}59.53 \\
(1.82)\end{array}$ & $\begin{array}{l}17.99 \\
(0.45)\end{array}$ & $\begin{array}{l}17.58 \\
(0.44)\end{array}$ \\
\hline $\mathrm{N}$ & 56 & 58 & 56 & 58 \\
\hline $\mathrm{R}^{2}$ & 0.83 & 0.84 & 0.57 & 0.56 \\
\hline
\end{tabular}




\begin{tabular}{|c|c|c|c|c|}
\hline \multirow{2}{*}{ Variables } & \multicolumn{2}{|c|}{ House } & \multicolumn{2}{|c|}{ Senate } \\
\hline & 1953-2008 & $1953-2010$ & $1953-2008$ & $1953-2010$ \\
\hline Party Control & $\begin{array}{r}-81.11 \\
(-4.16)\end{array}$ & $\begin{array}{r}-76.65 \\
(-4.57)\end{array}$ & $\begin{array}{r}19.65 \\
(6.21)\end{array}$ & $\begin{array}{r}20.78 \\
(6.46)\end{array}$ \\
\hline Honeymoon & -- & $\begin{array}{r}5.76 \\
(1.70)\end{array}$ & $\begin{array}{r}\mathbf{8 . 1 0} \\
(1.78)\end{array}$ & $\begin{array}{r}10.23 \\
(2.26)\end{array}$ \\
\hline Public Approval & -- & -- & $\begin{array}{r}\mathbf{0 . 2 4} \\
(1.74)\end{array}$ & $\begin{array}{r}\mathbf{0 . 2 1} \\
(1.55)\end{array}$ \\
\hline Party Polarization & $\begin{array}{r}\mathbf{- 1 . 0 5} \\
(-7.45)\end{array}$ & $\begin{array}{r}\mathbf{- 1 . 0 2} \\
(-7.47)\end{array}$ & $\begin{array}{r}\mathbf{- 0 . 3 3} \\
(-2.60)\end{array}$ & $\begin{array}{c}-\mathbf{0 . 2 2} \\
(-1.83)\end{array}$ \\
\hline Approval x Party Polarization & -- & -- & -- & -- \\
\hline Party Control x Party Polarization & $\begin{array}{r}1.71 \\
(5.99)\end{array}$ & $\begin{array}{l}1.63 \\
(6.70)\end{array}$ & -- & -- \\
\hline Constant & $\begin{array}{l}112.19 \\
(11.93)\end{array}$ & $\begin{array}{l}110.07 \\
(11.97)\end{array}$ & $\begin{array}{l}58.47 \\
(5.10)\end{array}$ & $\begin{array}{l}52.50 \\
(4.56)\end{array}$ \\
\hline $\mathrm{N}$ & 56 & 58 & 56 & 58 \\
\hline $\mathrm{R}^{2}$ & 0.81 & 0.83 & 0.55 & 0.55 \\
\hline
\end{tabular}

\begin{tabular}{|l|rr|rr|}
\hline \multicolumn{2}{|c|}{ Table 3. Predicting Obama's Success in 2009 and 2010 } \\
\hline & \multicolumn{2}{|c|}{ House } & \multicolumn{2}{c|}{ Senate } \\
& 2009 & 2010 & 2009 & 2010 \\
\hline Actual Success & 93.2 & 85.7 & 97.6 & 75.0 \\
\hline Predictions & & & & \\
1953-2008 Model & 88.5 & 92.0 & 71.4 & 63.3 \\
1953-2010 Model & 92.0 & 87.7 & 77.0 & 58.9 \\
\hline Residuals & & & & \\
1953-2008 Model & 4.7 & -6.3 & 26.2 & 11.7 \\
1953-2010 Model & 1.2 & -2.0 & 20.6 & 16.1 \\
\hline
\end{tabular}




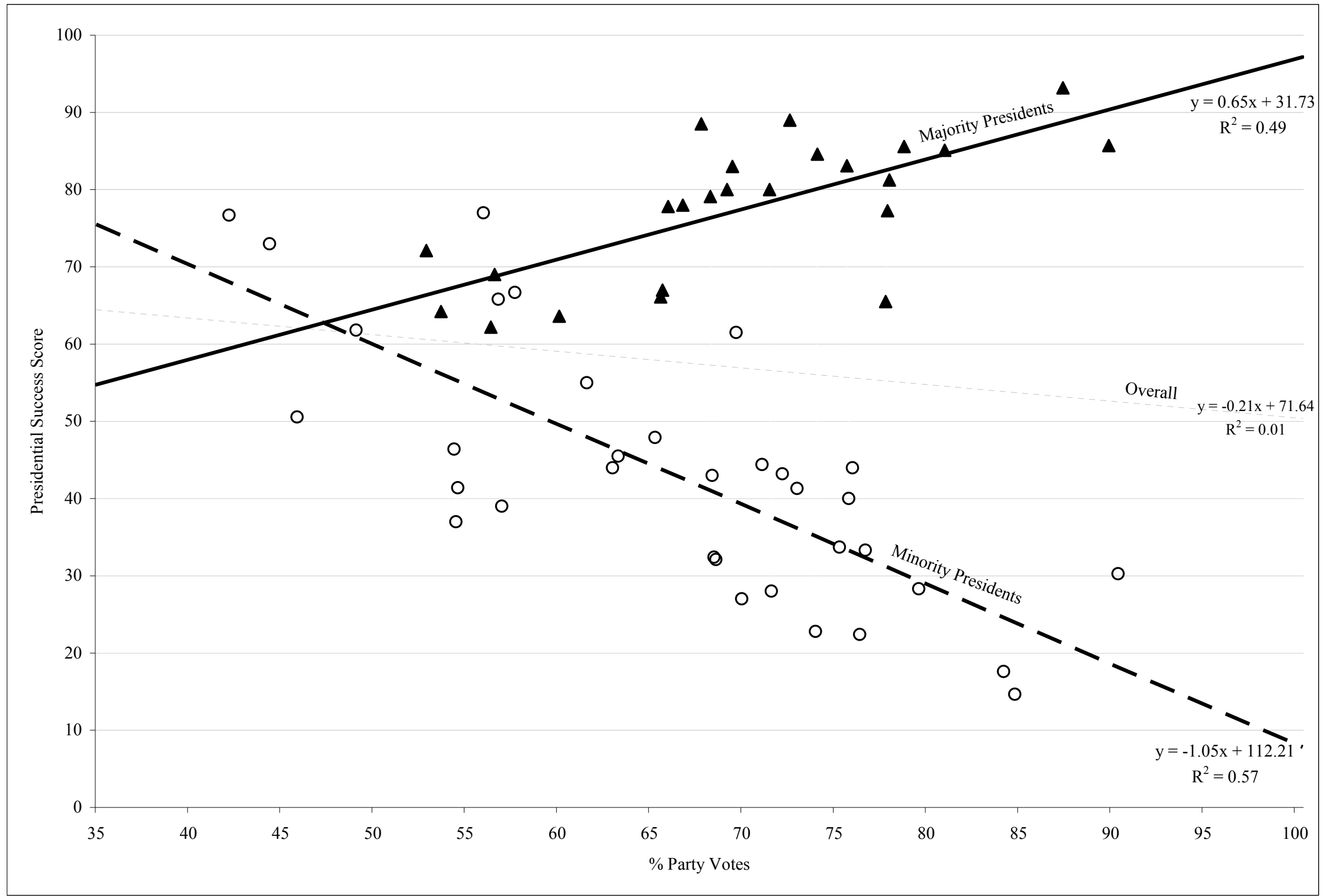

Figure 1: How Party Polarization Affects the Relationship between Party Control and Presidential Success in the House 


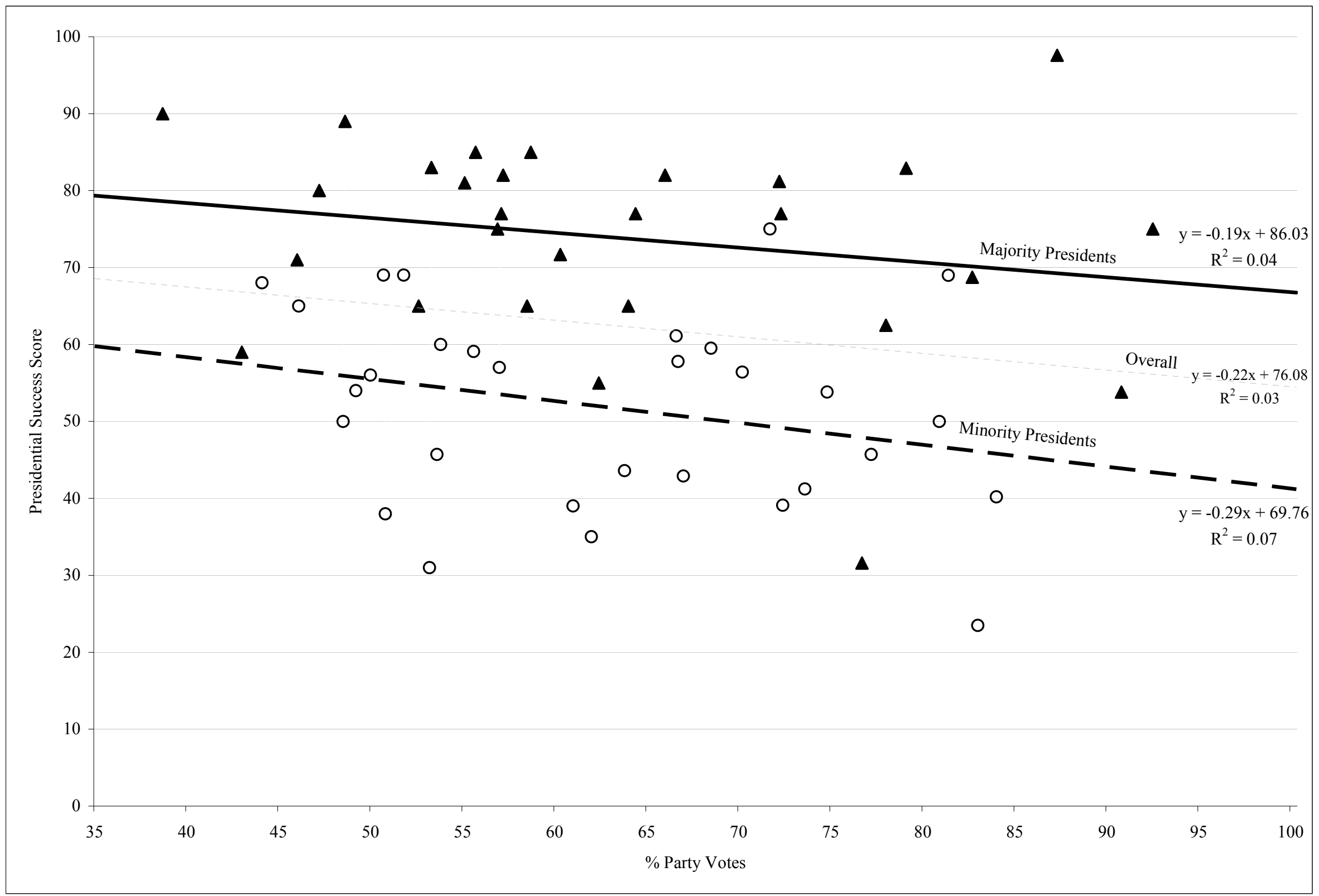

Figure 2: How Party Polarization Affects the Relationship between Party Control and Presidential Success in the Senate 


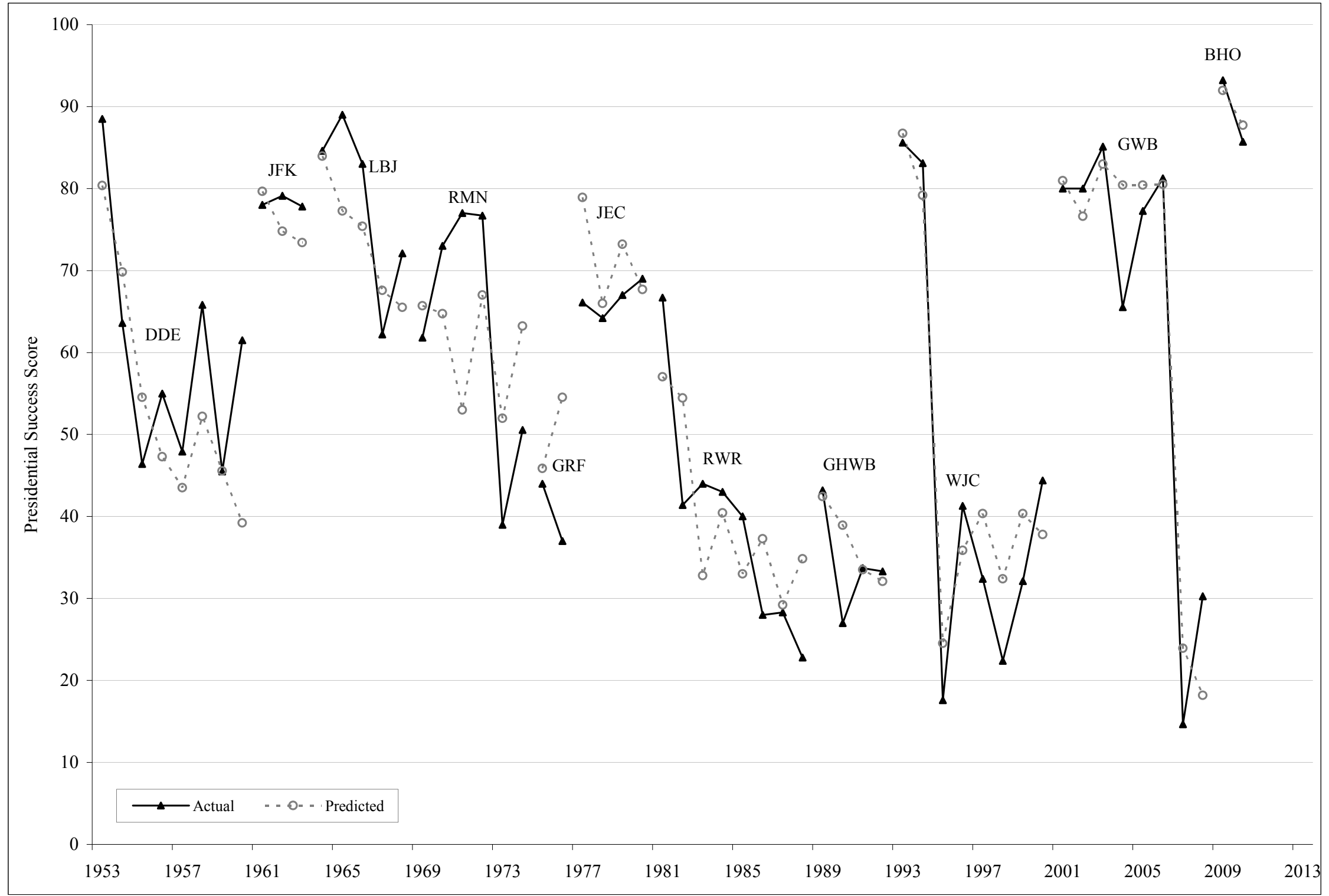

Figure 3: Actual and Predicted Presidential Success in the House, 1953-2010

Based on results from Table 2 


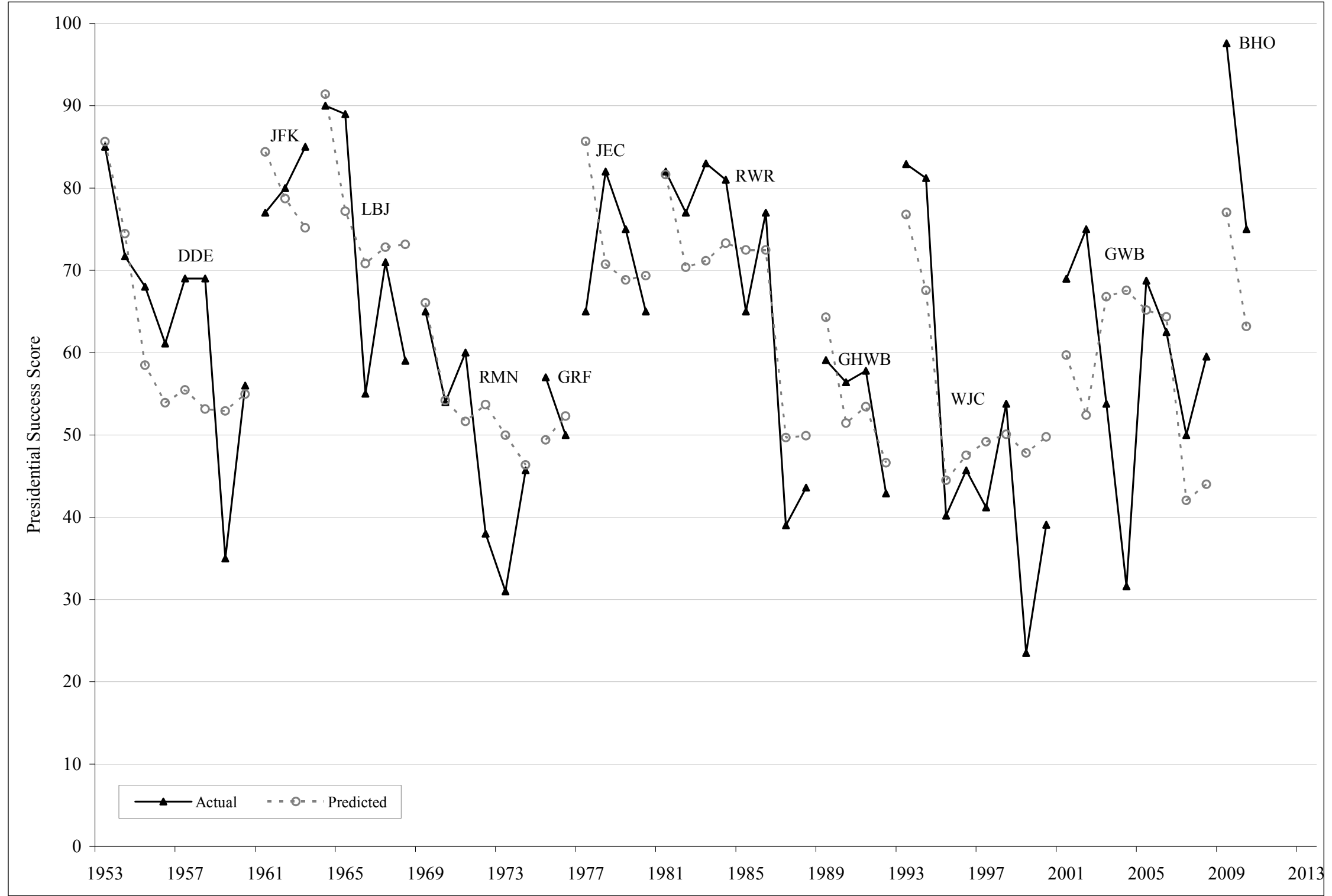

Figure 4: Actual and Predicted Presidential Success in the Senate, 1953-2010

Based on the results from Table 2 


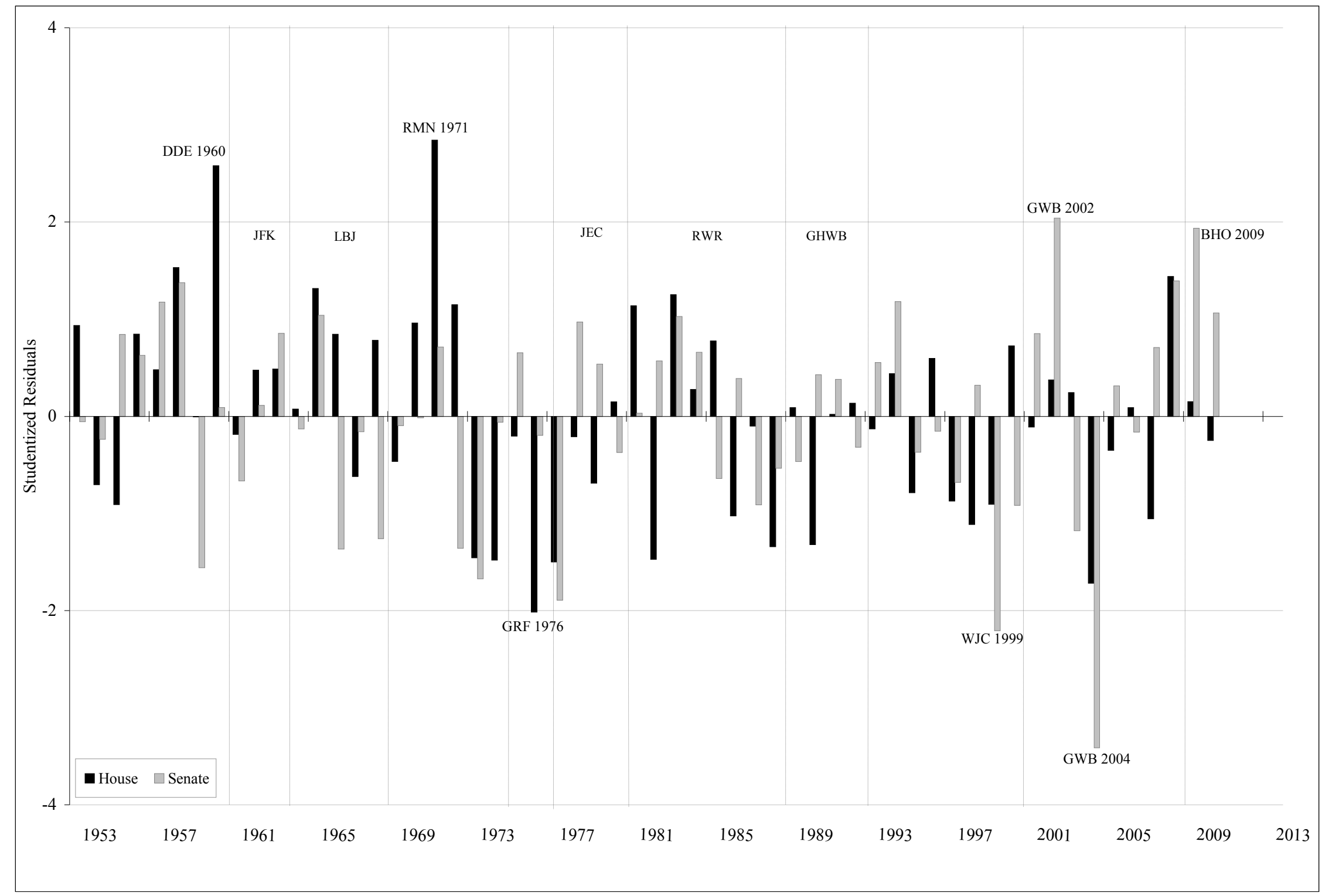

Figure 5: Which Presidents Were More or Less Successful than Expected in the House and Senate, 1953-2010? Based on results from Table 2 


\section{Notes}

${ }^{1}$ Fred I. Greenstein, “The Leadership Style of Barack Obama: An Early Assessment,” The Forum 7 (Issue 1 2009): 7-10, Article 6, http://www.bepress.com/forum/vol7/iss1/art6/, accessed on June 9, 2011.

${ }^{2}$ Stanley A. Renshon, "Redemption, Fairness, and the Politics of Transformation in the Obama Presidency," Political Psychology 32 (No. 6 2011): 1048.

${ }^{3}$ Peter Slevin, “Obama Forged Political Mettle in Illinois Capitol,” Washington Post, 9 February 2007, retrieved July 9 , 2012, from http://www.washingtonpost.com/wp-dyn/content/article/2007/02/08/AR2007020802262.html.

${ }^{4}$ Richard E. Neustadt, Presidential Power (New York: Wiley, 1960), 63.

${ }^{5}$ Roger H. Davidson, "The Presidency and Congress." in The Presidency and the Political System, ed. Michael Nelson (Washington, DC: CQ Press, 1984), 374.

${ }^{6}$ Alvin S. Felzenberg, The Leaders We Deserved (and a Few We Didn't): Rethinking the Presidential Rating Game (New York: Basic Books, 2008); Fred I. Greenstein, The Presidential Difference: Leadership Style from FDR to George W. Bush. $2^{\text {nd }}$ ed. (Princeton, NJ: Princeton University Press, 2004); Barbara Kellerman, The Political Presidency: Practice of Leadership from Kennedy through Reagan (New York: Oxford University Press, 1984).

${ }^{7}$ On legislative skills see Stephen J. Wayne, "Legislative Skills," in The Oxford Handbook of the American Presidency, George C. Edwards III and William Howell, eds. (New York: Oxford University Press, 2009): 311-337; Brad Lockerbie and Stephen A. Borrelli, "Getting Inside the Beltway: Perceptions of Presidential Skill and Success in Congress," British Journal of Political Science 19 (January 1989): 97-106 and Dennis W. Gleiber, Steven A. Shull, and Colleen A. Waligora, "Measuring the President's Professional Reputation," American Politics Research 26 (July 1998): 366-385 offer methods to measure a president's reputation for being skillful.

${ }^{8}$ Research on how political context affects on presidential success with Congress is huge. Recent studies include Andrew W. Barrett and Matthew Eshbaugh-Soha, "Presidential Success on the Substance of Legislation," Political Research Quarterly 60 (March 2007): 100-112; Matthew N. Beckmann, "The President's Playbook: White House Strategies for Lobbying Congress," Journal of Politics 70 (April 2008): 407-419; Matthew N. Beckmann, Pushing the Agenda: Presidential Leadership in U.S. Lawmaking, 1953-2004 (New York: Cambridge University Press, 2010); Jon R. Bond, Richard Fleisher, and B. Dan Wood, "The Marginal and Time Varying Effect of Public Approval on Presidential Success in Congress," Journal of Politics 65 (February 2003): 92-110; Brandice Canes-Wrone and Scott de Marchi, "Presidential Approval and Legislative Success," Journal of Politics 64 (May 2002):491-509; Cary R. Covington, J. Mark Wrighton, and Rhonda Kinney, "A Presidency-Augmented Model of Presidential Success on House Roll Call Votes," American Journal of Political Science 39 (November 1995): 1001-24; George C. Edwards, III, Andrew Barrett, and Jeffrey Peake, “The Legislative Impact of Divided Government," American Journal of Political Science 41 (April 1997): 545-63; Richard Fleisher, and Jon R. Bond, 2000. "Partisanship and the President's Quest for Votes on the Floor of Congress," in Polarized Politics: Congress and the President in a Partisan Era, eds., Jon R. Bond and Richard Fleisher, (Washington, DC: CQ Press, 2000), 154-185; Richard Fleisher, Jon R. Bond, and B. Dan Wood, "Which Presidents are Uncommonly Successful in Congress?" in Presidential Leadership: The Vortex of Power, eds. Bert A. Rockman and Richard W. Waterman (New York: Oxford University Press, 2008), 191-214; Matthew J. Lebo and Andrew O'Geen, “The President's Role in the 
Partisan Congressional Arena," Journal of Politics 73 (July 2011): 718-734; Frances E. Lee, Beyond Ideology: Politics, Principles, and Partisanship in the U.S. Senate (Chicago: University of Chicago Press, 2009); Brad Lockerbie, Stephen Borrelli, and Scott Hedger, “An Integrative Approach to Modeling Presidential Success in Congress,” Political Research Quarterly 51 (March 1998): 155-72; Bryan W. Marshall and Brandon C. Prins, "Strategic Position Taking and Presidential Influence in Congress," Legislative Studies Quarterly 32 (No. 2 2007 ): 257-284; and David W. Rohde and Meredith Barthelemy, "The President and Congressional Parties in an Era of Polarization." in The Oxford Handbook of the American Presidency, George C. Edwards III and William Howell, eds. (New York: Oxford University Press, 2009): $289-310$.

${ }^{9}$ Fleisher, Bond, and Wood, "Which Presidents are Uncommonly Successful in Congress?"

${ }^{10}$ George C. Edwards, III, At the Margins: Presidential Leadership of Congress (New Haven: Yale University Press, 1989); Jon R. Bond and Richard Fleisher, The President in the Legislative Arena (Chicago: University of Chicago Press, 1990).

${ }^{11}$ Covington, Wrighton, and Kinney.

12 Paul C. Light, The President's Agenda: Domestic Policy Choice from Kennedy to Carter (with Notes on Ronald Reagan) (Baltimore: Johns Hopkins University, 1982).

${ }^{13}$ See Matthew N. Beckmann and Joseph Godfrey, “The Policy Opportunities in Presidential Honeymoons,” Political Research Quarterly 60 (June 2007): 250-262; Casey Byrne Knudsen Dominguez, “Is it a Honeymoon? An Empirical Investigation of the President's First Hundred Days," Congress and the Presidency 32 (March 2005): 63-78; John, Frendreis, Raymond Tatalovich, and Jon Schaff, "Predicting Legislative Output in the First One-Hundred Days, $1897-$ 1995," Political Research Quarterly 54 (December 2001): 853-70; Keith Krehbiel, Pivotal Politics: A Theory of U.S. Lawmaking (Chicago: University of Chicago Press, 1998). Krehbiel argues that the Presidents and Congress work on the easier issues first, that is, issues with the highest chances for enactment, the strongest public backing, and the weakest opposition, which accounts for honeymoon effects.

${ }^{14}$ Neustadt, Presidential Power, 86.

15 John W. Kingdon, Congressmen's Voting Decisions, $2^{\text {nd }}$ ed. (New York: Harper and Row, 1981). Research presents a mixed picture on the effects of approval on success; See George C. Edwards, III, "Presidential Approval as a Source of Influence in Congress." in The Oxford Handbook of the American Presidency, George C. Edwards, III and William G. Howell, eds., (New York: Oxford University Press, 2009), 338-361.

${ }^{16}$ Bond and Fleisher, President in the Legislative Arena; Edwards, At the Margins; George C. Edwards, III, The Strategic President: Persuasion and Opportunity in Presidential Leadership (Princeton, NJ: Princeton University Press, 2009).

${ }^{17}$ Bond, Fleisher, and Wood, "Marginal and Time Varying Effects".

${ }^{18}$ John H. Aldrich and David W. Rohde, "The Consequences of Party Organization in the House: The Role of the Majority and Minority Parties in Conditional Party Government." in Polarized Politics: Congress and the President in a Partisan Era, ed. Jon R. Bond and Richard Fleisher (Washington, DC: CQ Press, 2000), 69; Bond and Fleisher, President in the Legislative Arena.

${ }^{19}$ Congressional Quarterly, Inc., "Presidential Support," Congressional Quarterly Almanac (Washington, DC: Congressional Quarterly, annually 1953-2012). 
${ }^{20}$ As in Bond and Fleisher, President in the Legislative Arena and Fleisher and Bond, Partisanship and the President's Quest for Votes"

${ }^{21}$ We measure party control with a dummy variable because most research demonstrates that the size of the president's party does not significantly affect success above the effects of party control. See Bond, Fleisher, Wood, "Marginal and Time Varying Effects" and because simple-majority control provides the president's party with control over the congressional committees and agenda. Experiments with the data used here confirm that party size has no effect beyond majority control. Lebo and O'Geen, "The President's Role in the Partisan Congressional Arena", however, find an independent effect for the size of the president's party beyond majority control. The effects of size of the president's party might be conditional on other factors, such as polarization and party loyalty, which tend to covary. Generally, as party loyalty rises, there will be fewer defections, and thus the president can win with a smaller majority. Moreover, there are other crucial pivot pointsfilibuster and veto pivots - that if party percentages crossed would strongly affect success rates, see Krehbiel, Pivotal Politics. Because instances of such large presidential majorities are rare, we do not include the party-size variable.

${ }^{22}$ Coding majority control in the Senate in 2001 presents a dilemma. The initial party line-up in the Senate was 50 Republicans and 50 Democrats-Independents, with Vice President Richard Cheney breaking the tie to give Republicans control of the chamber. On June 6, 2001, Senator James Jeffords (R-VT) switched to Independent, and handed control to the Democrats. Because there was essentially the same number of months before after Jeffords' switch, coding 2001 as either a majority or minority Congress is arbitrary. In this analysis, we code 2001 as a minority Congress, but coding 2001 as a majority Congress makes little difference in the results (available from the authors).

${ }^{23}$ The honeymoon concept is rooted in the legitimacy given to a newly elected president. Yet the Lyndon Johnson and Gerald Ford cases present an issue of how to code whether and when they received a honeymoon. Lyndon Johnson was elected Vice President and assumed office following the Kennedy assassination when there was a strong rally of public support. As a result, Johnson received an early honeymoon prior to his election as president. Gerald Ford was appointed, not elected, Vice President and became president after Nixon's resignation so we coded him as having no honeymoon. We experimented with different coding schemes, and the best empirical fit is to give LBJ a honeymoon in 1964 and not give Ford any honeymoon. We use an empirical standard in part because we are attempting to maximize how much variance the context variables will explain, and to see if skills account for the remainder. Also, historical analyses of these two presidencies indicate that Johnson, due primarily to his early victory on civil rights once assuming office, was rewarded with a surge of public support consistent with a honeymoon, but that Ford's pardon of Nixon, barely one month into his presidency, squandered any honeymoon that might have been developing. On Johnson see Robert A. Caro, The Passage of Power (New York: Knopf, 2012) and on Ford see Barry Werth, 31 Days: The Crisis that Gave us the Government We have Today (New York: Nan A. Talese, 2006).

${ }^{24}$ Alternatively, we could have used DW-Nominate to measure party polarization. The problem with DW-Nominate is that it uses the same value for both years of a congress. Our unit of analysis is year, not Congress. Therefore, the party-voting measure is superior for our purposes since it picks up yearly values. However, party voting and DW-Nominate are highly 
correlated, over +0.9 ; so there may be little practical implication to using one over the other than the temporal measurement issue.

${ }^{25}$ This is a change from BFW model. Beginning in the 2000s, the percentage of consensual roll calls increased greatly. Keeping consensual votes in the denominator understates the degree of partisanship in recent years.

${ }^{26}$ This specification differs from the original models (e. g. Bond, Fleisherl, and Wood, "Marginal and Time Varying Effects" and Fleisher, Bond, and Wood, "Which Presidents are Uncommonly Successful", which did not include the main effect party-votes variable. To specify fully an interaction relationship requires including the component variables and the product of the components - party control, presidential approval, party votes, and the interactions (presidential approval $\mathrm{x}$ party votes) and (party control x party votes). On interaction terms see Robert J. Friedrich, "In Defense of Multiplicative Terms in Multiple Regression Equations," American Journal of Political Science 26 (November 1982): 797-833 and Thomas Brambor, William Roberts Clark, and Matthew Golder, "Understanding Interaction Models: Improving Empirical Analyses," Political Analysis 14 (Winter 2006): 63-82.

${ }^{27}$ Diagnostics revealed no non-stationarity or autocorrelation. This allowed us to use OLS. Newey-West and various ARIMA estimations produced results similar to the OLS. These alternative estimations are available upon request.

${ }^{28}$ Fleisher, Bond, and Wood, Which Presidents are Uncommonly Successful?"

${ }^{29}$ Determining statistical significant in interaction models can be difficult because of high correlation between the interaction term and its constituent variables. We assess whether the inclusion or exclusion of a variable has a significant effect on overall model performance using an $\mathrm{F}$ test to compare the $\mathrm{R}^{2}$ of estimations with and without the variable. The formula is: $\mathrm{F}=\left\{\left(\mathrm{R}_{\mathrm{u}}{ }^{2}-\mathrm{R}_{\mathrm{r}}{ }^{2}\right) / \mathrm{q}\right\} /\left\{\left(1-\mathrm{R}_{\mathrm{u}}{ }^{2}\right) /(\mathrm{n}-\mathrm{k})\right\}$, where $\mathrm{u}$ and $\mathrm{r}$ stand for unrestricted (variable not included) and restricted (variable included); $\mathrm{q}=$ number of added restrictions; $\mathrm{n}=$ number of cases; $\mathrm{k}=$ number of variables in the unrestricted model (Fisher, 1970). We first test the interaction terms and then test the other variables. See Franklin M. Fisher, "Tests of Equality Between Sets of Coefficients in Two Linear Regressions: An Expository Note," Econometrica 38 (March 1970): 361-366.

${ }^{30}$ The standard deviation of public approval is 11.9 percent.

${ }^{31}$ Bond, Fleisher, and Wood, "Marginal and Time Varying Effects".

${ }^{32}$ Gergory Koger, Filibustering: A Political History of Obstruction in the House and Senate (Chicago: University of Chicago Press, 2010) and Gregory J. Wawro and Eric Schickler, Filibuster: Obstruction and Lawmaking in the U.S. Senate (Princeton, NJ: Princeton University Press, 2006).

${ }^{33}$ Jon R. Bond, Richard Fleisher, and Glen S. Krutz, "Malign Neglect: Evidence that Delay Has Become the Primary Method of Defeating Presidential Appointments," Congress \& the Presidency 36: (No.3 2009): 1-18.

${ }^{34}$ Greenstein, "The Leadership Style of Barack Obama".

${ }^{35}$ Fleisher, Fleisher, and Wood, "Which Presidents are Uncommonly Successful". Studentized residuals are standardized residuals made independent by calculating the model fit while sequentially omitting each of the $i$ observations. This constructs an index of the relative "unusualness" of observations, taking into account the leverage that an observation 
exerts, as well as the absolute size of each residual. Studentized residuals follow a t-distribution with T-k-1 degrees of freedom.

${ }^{36}$ The large residuals in the early part of the House time series and in the latter part of the Senate time series suggest the possibility of heteroskedasticity. Tests revealed no evidence of heteroskedasticity or omitted variables.

\begin{tabular}{|l|l|l|l|}
\hline \multicolumn{3}{|c|}{ Test for Heteroskedasticity and Omitted Variables } \\
\hline \multicolumn{1}{|c|}{ Test } & \multicolumn{1}{|c|}{ Null Hypothesis } & \multicolumn{1}{c|}{ House } & \multicolumn{1}{c|}{ Senate } \\
\hline $\begin{array}{l}\text { Breusch-Pagan / Cook-Weisberg test for } \\
\text { heteroskedasticity }\end{array}$ & Ho: constant variance & chi $^{2}(1)=2.14$ & chi $^{2}(1)=0.02$ \\
& & $\mathrm{p}=0.14$ & $\mathrm{P}=0.89$ \\
\hline Ramsey RESET test for omitted variables & Ho: no omitted variables & $\begin{array}{l}\mathrm{F}(3,50)= \\
0.20\end{array}$ & $\mathrm{~F}(3,50)=0.62$ \\
& & $\mathrm{p}=0.89$ & $\mathrm{p}=0.60$ \\
\hline
\end{tabular}

${ }^{37}$ Fleisher, Bond, and Wood, "Which Presidents are Uncommonly Successful".

${ }^{38}$ But see Fred I. Greenstein, The Hidden-Hand Presidency: Eisenhower as Leader (New York: Basic Books, 1982);

Robert Merry, Where They Stand: The American Presidents in the Eyes of Voters and Historians (New York: Simon and Schuster, 2012); and Jean Edward Smith, Eisenhower in War and Peace (New York: Random House, 2012).

${ }^{39}$ Light, The President's Agenda.

${ }^{40}$ Fleisher, Bond, and Wood, "Which Presidents are Uncommonly Successful". 